Article

\title{
Love Thy Extra-Terrestrial Neighbour: Charity and Compassion in Luc Besson's Space Operas The Fifth Element (1997) and Valerian and the City of a Thousand Planets (2017)
}

\section{Sylvie Magerstädt}

School of Humanities, University of Hertfordshire, Hatfield, Herts AL10 9EU, UK; s.magerstaedt@herts.ac.uk

Received: 13 August 2018; Accepted: 20 September 2018; Published: 27 September 2018

\begin{abstract}
The role of romantic love in cinema-and its redeeming aspects-has been extensively explored in film studies and beyond. However, non-romantic aspects of love, especially love for the neighbour, have not yet received as much attention. This is particularly true when looking at mainstream science fiction cinema. This is surprising as the interstellar outlook of many of these films and consequently the interaction with a whole range of new 'neighbours' raises an entirely new set of challenges. In this article, the author explores these issues with regard to Luc Besson's science fiction spectacles The Fifth Element (1997) and Valerian and the City of a Thousand Planets (2017). Both films have divided fans and critics and it is indeed easy to dismiss them as mere spectacle with little depth or message, as many reviewers have done. Yet, as this article demonstrates, beneath their shiny, colourful surface, both films make a distinct contribution to the theme of neighbourly love. What is more, Besson's films often seem to develop a close link between more common notions of romantic love and agapic forms of love and thus offer a perspective of exploring our relationship to the alien as our neighbour.
\end{abstract}

Keywords: Luc Besson; science fiction; Fifth Element; Valerian and the City of a Thousand Planets; neighbour love; agape; charity; space aliens

\section{Introduction-Science Fiction à la Française}

Much has been said about the redeeming aspects of romantic love in science fiction cinema. As emblematised, for example, in Neo's resurrection by a kiss from his beloved Trinity in The Matrix or Caster's sacrificial death at the end of Transcendence (2014), science fiction often posits love as the ultimate saving grace of humanity against the threat of both alien invasion and technological apocalypse. It is thus not surprising that French director Luc Besson made love a central theme in his science fiction blockbusters The Fifth Element (1997) and Valerian and the City of a Thousand Planets (2017). With their spectacular and brightly coloured sets, as well as an equally colourful array of characters-both alien and human-the films have divided fans as well as critics. The Hollywood Reporter, for example, criticised the earlier film for its 'hyper-busy, threadbare and, ultimately, incoherent narrative' and was not much kinder with Valerian when calling it 'unclear, unfun, indecipherable, indigestible' (Byrge 1997 and McCarthy 2017). In contrast, Nathan Rabin (2018) in The Guardian is more favourable, suggesting that when 'Besson is working on a big canvas, as with 1997's The Fifth Element, a film with the straight-faced audacity to posit that love truly is the fifth element, it becomes impossible to deny his auteur status.' He adds with regard to Valerian that two 'decades after The Fifth Element was a worldwide box-office success and attained instant cult classic status, Besson has made another magnum opus, another labor of love, another movie that is so personal that it's essentially Luc Besson in cinematic form' (Rabin 2018). And, as I hope to demonstrate, beneath their shiny surface, both films 
also have something to say about the theme of neighbourly love, even if one can easily be distracted by all the action. One of the advantages of cinema, as Hansen (1997, p. xxxiii) puts it, is that even if it tries 'to direct our attention' it 'also afford[s] us an opportunity to meander across the screen and away from it, into the labyrinths of our own imagination'. Besson's films offer such as opportunity. And, as we are caught up in the action, we are also inspired to reflect about more universal ideas. While we enjoy the breathtaking visuals, a part of us may register the lessons we are taught about loving our extra-terrestrial neighbours.

The notion of Besson as an auteur, though controversial with regard to the films under discussion, is one of the reasons for choosing these particular films for my analysis. Despite their blockbuster style action and visuals, they are quite distinct from more mainstream Hollywood science fiction films. As such, they also offer new ideas outside the standard genre tropes. As Hayward (1999, p. 248) has outlined in her essay on The Fifth Element, Besson 'is trying out [ ... ] ideas with the technology available [ ... ], which it is unlikely Hollywood would attempt.' More specifically, she notes that in 'this oversized humanated scope cartoon, good triumphs over evil; and France triumphs over Hollywood. As Besson himself makes clear, no American major would have touched the script' (Hayward 1999, p. 256). In a later essay, she adds that The Fifth Element was at its time one of few science fiction films that emphasised that we, rather than technology, were responsible for destroying our planet (Lewis and Powrie 2009). Twenty years later, this theme has become more widespread in science fiction cinema. Besson's latest work Valerian picks up these threads, exploring environmental issues with regard to interracial and inter-species relations.

The value of science fiction for exploring themes such as love, forgiveness and faith has been noted, and I will outline in more detail later, how these are played out in Besson's films. More generally, as Sardar (2002, p. 4) suggests, science fiction as 'a genre devoted to the great secularising force, science', does provide 'a medium for ethical and moral speculation' in 'an increasingly secular age'. In addition, he suggests that the 'most conventional moral in science fiction is a belief in humane principles, value-laden precepts that have no place in science' (Sardar 2002, p. 4). As I will demonstrate, however, Besson subverts this central idea in interesting ways and challenges the idea of our moral superiority.

In exploring issues of neighbourly love, I will focus on the role of love as a virtue that guides the actions of the leading characters. In the process, I will also draw on related virtues such as compassion and forgiveness that are closely connected to Besson's concept of love for the neighbour. Before analysing Besson's films in more depth, let us first look briefly at the key aspects of agapic love and the ways in which extra-terrestrial beings have been portrayed in cinema. This will provide the basis for exploring the biblical question 'Who is my neighbour?' in Besson's colourful universe, where the contact with other planets and their inhabitants is the norm rather than the exception.

\section{It Is All about Love}

In his study on the theological history of love, Lindberg (2008, p. 13) suggests that the 'biblical perspective viewed human love from a theocentric perspective-love to [sic] others is to be analogous to divine love.' He further outlines that 'the Greek translation of the Hebrew Bible and the Greek New Testament used agape to designate at the same time the creating and redeeming love of God to the world and to humankind, the reciprocal love of humankind to God, and the love of persons as the witness of human love to God' (Lindberg 2008, p. 14). Thus the term agape, or agapic love is often used to denote both divine love and neighbourly love and I will use it in this sense throughout this article. Yet, the various love relations indicated in this quote also indicate the complexity of the notion of the love commandment and the struggle of many scholars in finding the right balance between a preferential love of our nearest and dearest and a more universal kind of love that has scope to include not just love for strangers, but even love for the enemy. It is not surprising that a medium like cinema, in which storytelling is largely focussed on the individual (at least in its mainstream forms) has focussed more on aspects of preferential love - romantic, parental-than on the more intangible concepts, such as love for all humanity. As a principle of faith, it is hard to visualise. Miles (1996, p. 45) wonders 
with regard to faith how something 'as interior and invisible' can be communicated in 'a medium in which things must be visible to be real'. She does, however, acknowledge that Hollywood has an iconography for 'signalling another invisible state-love' (Miles 1996, p. 45). It expresses emotions trough audio-visual means, for example gestures and music. But, there may be a problem with this. As many writers on love, both romantic and neighbourly, have argued, love is not just a feeling. C. S. Lewis (1952, p. 129), for example, emphasised that 'love, in the Christian sense, does not mean an emotion. It is a state not of the feelings but of the will; that state of the will which we have naturally about ourselves, and must learn to have about other people.' In addition, Lindberg (2008, p. 16) outlines that agape was translated into Latin by three words: caritas, dilectio, and amor, and the most relevant for our discussion-caritas-designates both 'the love of God and [ ... ] ethical virtue'. This aspect of love as a virtue further emphasises its nature as a disposition to act in certain ways rather than just an emotion. Yet, the film conventions developed to denote love (camera angles, acting strategies) are strongly linked to the expression of emotions and may thus get in the way of us seeing the wider scope of love.

Another problem is that in the intellectual history of love, some writers have positioned romantic and agapic love as in conflict with each other. For instance, Lindberg (2008, pp. 15-16) notes that the early twentieth century Swedish theologian Anders Nygren (1953) controversially argued that 'the distinctive character of the Christian concept of love, agape [stands] in contrast to the Greek concept of

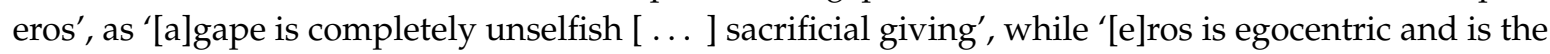
highest form of self-assertion'. This might cause a problem in a medium that has a strong preference for romantic love. Yet, as Lewis has outlined, what he calls need-love (love that emerges from our individual needs for, say, safety, companionship or friendship) and the self-sacrificial gift-love given to us by God are not necessarily in conflict with each other. As I will explore in more detail later on, gift-love can actually transform need-love, so that its focus is more on others. Paul Wadell (2014, p. 381), for example, emphasises that caritas or, in the anglicized version, 'charity makes every human being "another self" to us precisely because we are bonded to them in the universal fellowship of those who have been befriended by God.' As a consequence, '[c]harity reshapes how we see other persons' (Wadell 2014, p. 387). Lindberg (2008, p. 59) outlines that '[c]aritas in Augustine's sense is primarily love to God made possible because God first loved humankind. Love to God is the central virtue; all other virtues are expressions of it.' Similarly, Taliaferro (2012, p. 181) notes that the 'Christian teaching that God first loved (and loves) us before we love God also provides a deep view of love as having an antecedent, foundational role in our lives.' While divine love is the basis for our love, this love is expressed through interaction with others. Particularly, Reformation theology emphasised this aspect and stipulated that 'a Christian lives not in himself, but in Christ and in his neighbour. [ ... ] He lives in Christ through faith, in his neighbour through love' (Martin Luther, 'On the Freedom of a Christian', Luther 1520; cited in Lindberg 2008, p. 132).

Yet, the question remains, to whom we apply this neighbourly love. And indeed, the answer given by Jesus in the Bible-in form of the parable of the Good Samaritan (Luke 10: 29-37) -is that '[w] hoever is in need is the neighbour' (Lindberg 2008, p. 29). Yet, is it possible to expand this notion of the neighbour to make it truly all-inclusive-and to push it beyond the boundaries of our human species? ${ }^{1}$

\section{The Alien and I-Extra-Terrestrial Neighbours in Science Fiction Cinema}

Aliens have always played a special role in science fiction narratives. Unlike man-made robots and cyborgs, their portrayal as either 'monstrous Other' or 'a bit like us' reveals many deep anxieties about our own sense of self. Moreover, as Schwartz Ellis (2004, p. 146) suggests, 'through watching

1 Francis of Assisi famously already included animals, plants, and the forces of nature in the command to love God and these thoughts also play a role in contemporary debates on animal ethics (see, for example, the works for Andrew Linzey). It is, however, beyond the scope of this paper to explore this here in more detail. 
space alien films, we are getting in touch with our roots, exploring the secret, sacred dimension of our scientific worldview.' Our attitude to science and its relation to moral questions is a core element of science fiction narratives, but it takes on a special role with regard to aliens. Sardar (2002, p. 5) argues, maybe controversially, that

good people make bad science is not its trope at all [in science fiction]. Villainy and evil are not within, intrinsic in science, they are dei ex machina, external elements that enter to disturb the equilibrium, external elements that unlock doomsday and thereby permit the definition of the redemptive and normative view of science and humanity. And this is why science fiction needs aliens.

Recent science fiction, in particular, has undermined this notion of villainy being always external. Films like Ex Machina (2014) and Transcendence (2014) have highlighted that good (although not necessarily in a moral sense) scientists can indeed create dangerous science. The notion of evil in science fiction is, moreover, influenced by the convergence with other genres, which challenges the clear-cut notion of evil as otherness proposed by Sadar. Thomson (1998, p. 7), for example, suggests that in 'sci-fi, genius has produced monsters of reason. But the horror genre knows we do not need science to dream of terrible dark shapes and forces. Our deepest nature summons them, and with it the delicious dread-call it religious or psychological-that we deserve them, and cannot function without them.' As we will see, Besson's science fiction fantasies also undermine the generic conventions suggested by Sadar. Although he does not necessarily draw on horror conventions, his films nevertheless expose the destructive tendencies that are also part of the human endeavour.

More interestingly, for Sadar, our treatment of aliens as the dangerous other is also linked to our own history. In contemporary science fiction, he argues, 'the whole universe is populated by fictional creatures [ ... ] springing almost unchanged from the pages of travel literature of the history of Western expansion on planet Earth' (Sardar 2002, pp. 5-6). This is also evident in Besson's films. The floating Chinese food seller that tries to uplift Korben Dallas with fortune cookie wisdom in The Fifth Element, or the oriental market guide in Valerian with his oversized turban, are clearly such fictional creatures. Yet, their exaggerated and jarring appearance in the high-tech worlds of the future also instantly exposes them as stereotypes that now seem out of place.

Taking a broader view of the aliens that populate contemporary science fiction cinema, Lyden suggests that their portrayal-like that of other features such as robots and time travel-is dualistic in nature. They 'may be represented as demons or angels, a threat to survival or virtuous saviors' (Lyden 2003, p. 206). Their appearance in either form also went through significant cycles in the history of science fiction cinema. Still, dangerous aliens may be for many the most common trope associated with the genre. For Sardar (2002, p. 6), one of the key works of early science fiction, H. G. Wells' The War of the Worlds, 'returns to the very beginning of Western storytelling', where Earth is threatened 'by an incomprehensible scourge bent on destruction'. The aliens of the story 'are unknowable, fanatic, equipped with superior technology, bloodthirsty, merciless and cruel' (Sardar 2002, p. 6). Their appearance is often monstrous, in contrast to the often more humanoid portrayal of 'good aliens' as I will highlight shortly. Nevertheless, it may be too convenient for us to simply dismiss them as 'not human'. For when 'aliens are evil', as Lyden (2003, p. 206) observes, 'they also tend to reflect our worst side as they exaggerate our own faults, through being excessively violent and genocidal'. Especially early cinematic works, such as The Thing from Another World (1951), The War of the Worlds (1953), Invaders from Mars (1953), Killers from Space (1954) and Invasion of the Body Snatchers (1956 and its remake 1978), portray aliens as dangerous, reflecting Cold War anxieties and the fear of nuclear Holocaust. More recently, films like Independence Day (1996) and the 2005 remake of War of the Worlds revived those anxieties in the light of global challenges. At the same time, the science fiction comedy Mars Attacks! (1996) cleverly satirised the 'bad alien' trope of those more serious works. In addition, the famous Alien franchise and its subsequent Alien $v$. Predator crossovers emphasised the aforementioned connections between science fiction and horror, exploring themes of otherness in increasingly complex and varied ways. 
On the other hand, aliens have not always been the villains of science fiction cinema. In a range of alternative stories, the alien was used to 'show up the failings, internal corruption and fall from grace of Western civilisation' (Sardar 2002, p. 11). For example, both the Star Wars (1977-) and Star Trek (in cinema from 1979) franchises feature good as well as bad aliens, sometimes as enemies, sometimes as partners and collaborators. As Schwartz Ellis (2004, p. 145) notes, 'during the 1970s [ ... ] space aliens returned ... in much less threatening form'. She further suggests that 'these kinder, gentler aliens [ ... ] addressed our deep fears about technology and answered spiritual questions about our destiny' (Schwartz Ellis 2004, p. 145). This indicated a shift away from the political concerns of the Cold War to more universal and spiritual issues. The range of humanoid aliens that appeared during this and the following decade raised some profound questions about ourselves. Films such as E.T. the Extra-Terrestrial (1982) and Cocoon (1985) emphasised the benevolent qualities of visitors from outer space and explored themes of friendship, trust and eternal life.

To some extent, science fiction here reversed the notion of otherness by creating aliens 'in our image'. And, if they are like us-rational, emotional, social beings-it stands to reason that the love commandment should apply to them in the same way. In Leviticus (19: 34) we read that the 'alien who resides with you shall be to you as the citizen among you; you shall love the alien as yourself, for you were aliens in the land of Egypt'. ${ }^{2}$ The sacred text makes clear that the 'neighbour is not just the fellow Israelite but also the non-Israelites who were already living in the land but were not integrated socially or religiously' (Lindberg 2008, p. 20). However, Lindberg (2008, p. 21) also emphasises that 'although some of the prophetic writings suggest that God's love is universal, extending to all peoples, the Hebrew Bible does not actually speak of the love of God reaching out beyond Israel. The command to love the alien appears to refer to the resident alien'. As we have seen, Christian teaching later expands this concept towards all those in need (Luke 10: 29-37). Yet, even if taken in its more narrow sense of 'those we share space with', the concept of the neighbour is still applicable in the case of Besson's two science fiction films. In both cases, the alien is indeed living among us and therefore should be worth our consideration, not just in a general, but also in a particular sense. As Wadell (2014, p. 383) suggests, '[c]harity binds us to others as nothing else can-it makes us neighbors with everyone-because it is a fellowship based not on nationality, not on race, ethnicity, gender or even religion, but on God "communicating" his love and happiness with all persons'.

There is another aspect in which the 'good' alien is relevant for our discussion of agapic love. Robert Wise's science fiction classic The Day the Earth Stood Still (1951), for example, was unusual for its time as it featured a humanoid alien trying to convince humankind to turn away from their destructive ways. Not surprisingly, a number of scholars note, as Sardar $(2002$, p. 12) does, that 'the alien in The Day the Earth Stood Still could be interpreted as a biblical prophet, returned to rekindle the ethic internal to the West and thus save it from itself with its own ideas.' The 2008 remake of the film replaces the Cold War theme of nuclear warfare with the more contemporary problems of environmental damage, an issue that also appears in the background of both Besson films. Yet, both versions feature a powerful and benevolent alien coming to save us, which is ultimately rejected out of ignorance. It is not difficult to draw religious parallels here to the story of Christ and as I will outline shortly, Christ allusions also appear in The Fifth Element.

In the same year as Besson's earlier film, two other works also addressed our interaction with alien species. In Contact (1997), chief scientist Dr Eleanor Arroway (Jodi Foster) explores the possibilities of space (and time) travel in order to make first contact with an alien race. This raises a number of

2 Although most English translations of the Bible prefer to use the terms 'stranger' or 'foreigner' to translate this passage, a number of recent translations use the term 'alien', e.g., Christian Standard Bible (CSB), International Standard Version (ISV), Lexham English Bible (LEB) and the New Revised Standard Version (NRSV). The citation here is based on the NRSV. Interestingly, all these versions emphasise closeness to the original Greek and Hebrew texts. While the term alien is naturally not taken to mean 'extra-terrestrial' it nevertheless emphasises the notion of complete Otherness of those that we should consider neighbours. 
interesting religious concerns, for example, if a sceptical scientist who does not believe in God is representative of the human race. ${ }^{3}$ Issues of belief are addressed in a more humorous way in Men in Black, which explicitly portrays aliens as (legal and illegal) immigrants to our planet. Humanoid aliens also appear increasingly in superhero franchises, most notably with regard to Superman. Films like Man of Steel (2013) revive the idea of an extra-terrestrial saviour with allusions to biblical prophets or Christ figures. Schwartz Ellis (2004, pp. 148-49) also notes the divine associations, when talking about these positive aliens as sky gods, 'mysterious and remote beings whose Earthly appearances are associated with times of cosmic creation or collective crisis.' She proposes that it 'is the archetypal pattern of the sky god that can be traced in the careers of our cinematic aliens' (Schwartz Ellis 2004, pp. 148-49). This positioning of aliens as divine beings is also relevant for my discussion of agapic love as divine love. As I will illustrate below, by 'acting in profane time [these superior aliens] are actively demonstrating that moral perfection can extend into ordinary existence' (Schwartz Ellis 2004, p. 150). In Besson's films, it is indeed the alien as divine being that teaches us what it means to love in a sacrificial, non-selfish way.

\section{Love as Sacrifice in The Fifth Element (1997)}

Besson's 1997 science fiction blockbuster The Fifth Element features a wide range of alien creatures, good, bad and ambiguous. Yet, interestingly, this does not necessarily match up to the notion of humanoid equals good versus monstrous equals bad that was suggested by Schwartz Ellis (2004). In fact, the monstrous evil has no real form at all and appears as a large asteroid that swallows everything in its path like an enormous black hole. In contrast, one of the most positive alien figures in the film is the Diva (Maïwenn), a blue, lobster like opera singer, trustworthy enough to carry the stones representing four of the elements needed to dispel evil. When the hero of the film, ex-soldier and now taxi driver Korben Dallas (Bruce Willis), hears her sing, he is visibly moved and for the first time in the film shows a sense of awe that seems to almost overwhelm him. He clearly treats her as a fellow being in the same way that he helps the more humanoid Leeloo (Milla Jovovich). The latter is the eponymous fifth element, in the form of an attractive humanoid female. Her status as an 'alien', as Brown (2007, p. 94) argues, is amongst other things initially 'highlighted by [her] lack of language', which is consistent with other central heroes and heroines created by Besson. In many ways, Leeloo reflects what Hayward (1999, p. 249) described as 'postmodern nightmare', a place

where the modernist world is crumbling in the face of a virtual world that is post-narrative, post-photography, and post-biological. The paradox of Besson's movie is that Leeloo, the supreme being, embodies or-better put-is the site where these two worlds collide. The love story, which is one of the core narratives, is bound up with the race against time ... This traditional narrative is under constant threat from a techno-erotics ... in which the technology to delete the body threatens to outsmart more conventional ways of resolving crisis (through love and intelligence).

The Fifth Element indeed 'depicts twenty-third century New York as a technologically advanced society ... where Leeloo her/itself is a technological creation, having been "reconstructed" from a DNA sample' (Brown 2007, p. 95). Although she is regularly described as a perfect woman, her feminine attributes are rather toned down, as she is slim and androgynous with wild, straw-like orange hair. This in some ways supports the notion of her as a mythical or even divine creature. As Schwartz Ellis (2004, p. 146) proposes, quoting Mircea Eliade (1962), 'Androgyny is an ancient attribute of the Gods ... [thus representing a form of] divine "totalisation" [that] forms a simultaneity of cosmos and chaos'. In addition, her childlike innocence as well as her apparent vulnerability and willingness to

3 In the film, religious author Palmer Joss (Matthew McConaughey) argues (initially successfully) that Arroway should not be the one chosen to make 'first contact', because she does not believe in God. 
sacrifice herself also make her a Christ figure, albeit with a twist. As Flesher and Torry (2007, pp. 206-7) have suggested, 'The Fifth Element presents its main alien protagonist as a Christ who is opposed by an alien figure of pure evil at an ordained time of the apocalyptic end.' Although for Hayward (1998, p. 178), she is simply 'a woman-child that needs a man to liberate her', her need for help is not always a weakness. Unlike what Hayward claims, Leeloo educates herself and is rather demanding in asking for help. Her initial child-like attitude also relates her to a messiah that was being born as an innocent babe. By asking Korben for help, she also teaches him about love, even if she claims she does not know it, and thus changes his life in profound ways. As Flesher and Torry $(2007$, p. 207) have expressed it:

The savior arrives despite the attempts to prevent her and astounds everyone, including the priests, because in her perfection she combines femininity, beauty, strength, agility, and high intelligence. Yet she remains innocent and vulnerable, despite her commitment to her salvific mission. In the end, [ ... ] she takes the world's evil upon herself-in the knowledge of all humanity's wars-and then sacrifices herself on the temple's altar to become the channel for the light that triumphs over darkness.

Leeloo is the ultimate 'alien made in our image' as her DNA is like ours. Yet, she is also 'superhuman' as the complexity of this DNA is an enormous multiplicity of ours. Although she is recreated by humans from a DNA sample that is the only surviving fragment of a space ship meant to save the world, her origin remains mysterious. It is never made clear if she was created or if she somehow 'emerged' as a manifestation of the divine light that she channels at the end of the film. She is divine love become flesh. Hayward (1998, p. 179) argues rather dismissively that '[d]espite her incomprehension of [ ... ] mankind's drive to self-annihilation [ . . ] Leeloo is in the end persuaded that man is worth saving after all and that love, as embodied by Korben Dallas, is a sufficient reason to want to save the world.' But, she fails to recognise the sacrificial gift-love presented by Leeloo, a love given despite all the odds: 'forgive them; for they do not know what they are doing' (Luke 23: 34). Rather than just enacting a romantic gesture, Korben has to allow himself to be vulnerable in order to enable Leeloo to save him and the world. And this is asking a lot of a man who is used to single-handedly saving the world (as is suggested by his former army commander earlier in the film, as well as Bruce Willis' star persona). With only seconds to spare it seems that the only way to save them is to confess his love to Leeloo. You would think it were easy to say 'I love you' in the circumstances. And yet, Korben hesitates. He needs encouragement from the priest, not because he does not feel it, but because he realises that this means dropping his defences. As C. S. Lewis (1960, p. 120) puts it succinctly: 'There is no safe investment. To love at all is to be vulnerable.'

Now, one can argue that although Leeloo's love is sacrificial, it is still ultimately a story of romantic, rather than neighbourly, love. But, I propose that this is not the driving element from the outset. When Leeloo crashes out of the sky into Korben's life (or his taxi, to be more precise) at the beginning of the film, like the sky gods described by Schwartz-Ellis, his first instinct is to comply with the police attempting to arrest Leeloo. Having escaped from the research lab that recreated her, she is injured, dirty and desperate. Korben is swayed by her cry for help, not by her female allure. He can barely see her properly, lying wounded in a heap at the back of his cab. I think that what can be found here is something much closer to the story of the Good Samaritan. It is worth emphasising here that the Samaritan in that story was not just a stranger, but belonging to a race that was actively despised and excluded by the other residents. Thus, by using a Samaritan in this parable (as well as in the story of the Samaritan woman in John 4:4-26), the Bible authors emphasise the Otherness of those to whom we should show kindness, and who show kindness to us. While the researchers and the police treat Leeloo as an alien, as ultimate Other, not worthy of the same respect and treatment as their fellow citizens, Korben recognizes her as a fellow creature in need. He ignores the rules of his society and puts her needs first. As I will demonstrate shortly, a similar motif appears later in Valerian, when at the crucial turning point of the film, the hero is asked to take a risk and to defy orders in order to comply with the higher demands of (neighbourly) love. 
I suggested earlier that Besson manages to intertwine romantic love with other, maybe less obvious expressions of love. As Cubitt (2002, p. 18) notes, French science fiction cinema often emphasises 'the theme of home and nature lost under the burden of transnational capital'. Unlike other, more pessimistic works of the period, such as Jean-Pierre Jeunet's Delicatessen (1991), The Fifth Element expresses a 'mystical belief in the healing power of virtue ([ . . ] addressed as Love and emblematised as sex)' (Cubitt 2002, p. 19). Cinema may sometimes struggle to express the more subtle manifestations of love, which are all too easily overshadowed by the more familiar notions of romance, but they are nevertheless there. And, as demonstrated in the next section, Besson returns to the theme of agapic love in his most recent work of science fiction.

\section{Genocide, Love and Forgiveness in Valerian and the City of a Thousand Planets (2017)}

Twenty years after the success of The Fifth Element, Besson has drawn on a 1960s French comic strip to produce Valerian and the City of a Thousand Planets. The film is, in the words of one reviewer, a 'big, bright celebration of love and diplomacy among the shimmering poop-pearls of the outer reaches of the universe. A rollicking space adventure that's light on mythology (not a Chosen One to be found!) but generous on spirit' (Reid 2018). While the religious allusions in the latter film are certainly more subtle than the Christ analogy and mythical background in The Fifth Element, Valerian has nevertheless something to say about agapic love. Its spirituality is certainly more diffused with the cyber-universe in which it appears. This is in line with a contemporary cyber-spirituality expressed in other recent works, such as Avatar (2009), which happily blend technology, materiality and religion, as I discuss elsewhere (Magerstädt 2014). In Valerian, the aliens no longer descend to Earth to save humanity, but instead try to save their own world from the humans. Yet, love still matters, especially love in the form of forgiveness.

Valerian also reflects what Sardar $(2002$, p. 5) notes with regard to science fiction more generally, namely that it 'is both afraid of science and in love with science.' There is evidence for this in both of Besson's films, but it appears especially strong in Valerian. Unlike the native species featuring in Avatar, the 'Pearl people' in Valerian combine a naturalist, New Age spirituality, with a keen scientific interest. The latter enables them to create technology so advanced that it outsmarts all attempts by the combined human forces to identify it. They acquire the necessary knowledge autodidactically (linking them to Leeloo and her acquisition of skills from the internet) when they are forced out of their paradisiac planet. The link between knowledge and lost Edenic innocence is not too subtle here. But, with their new skills, the Pearls are able to build a highly complex virtual environment that recreates the nature paradise of their destroyed home planet. In a way, this subverts Hayward's postmodern nightmare as the virtual world helps to recreate the actual, lost world. The film here also draws on what Cubitt (2002, p. 23) calls the 'icon of ecological harmony, the seashore, where land and water, finite and infinite, meet as equals on a shifting border, and where the idyll of a re-naturalised humanity can be lived out, washed by the purifying waters of Ocean.' Unlike the jungle setting of Avatar, the planet Mül-original home of the Pearls and destroyed as collateral in a human space war-looks like a tropical beach paradise. Already in The Fifth Element, key scenes take place in a similar setting, Fhloston Paradise, a holiday destination for the rich and famous. Yet, the natural paradise of the earlier film is only admired from the safe and distant confines of a luxury cruise (space) ship. In both cases, it appears that the real paradise is ultimately inaccessible.

The destruction of Mül in Valerian is interesting because it emphasises the ecological concerns already raised in Besson's earlier film. But beyond that, it is the motif of deliberate genocide of an alien species, which raises ethical issues. This is in stark contrast to the opening sequence of the film, which starts with real footage from the current space station. Gradually, the film shows increasingly ethnically diverse crews arrive to be welcomed by the resident commander-Chinese, Indian, Arab, African, Mongol-until in 2050 the first alien race appears. Overall, the images and the accompanying off-screen narration emphasises a peace and unity message that is meant to include all races (human and alien). It is symbolised in the space station Alpha, the titular 'city of a thousand planets', on which 
over three thousand species live, if not in perfect harmony, then at least in peaceful coexistence. Thus, the notion of the neighbour as 'those you share the land with' becomes immediately relevant to alien and humans alike. However, this multicultural utopia is immediately undermined by a cut to the destruction of Mül. It is not clear at this point that this was a deliberate decision taken by Commander Arun Filitt (Clive Owen) in order to avoid costly compensation claims. But, there is already a sense of the injustice done to the Pearls, which becomes a driving factor of the film. As I argue below, the notion of justice is also related to agapic love.

Lindberg (2008, p. 163) notes that the philosopher and theologian Paul Tillich (1960), in particular, 'called for a more inclusive view of love and stressed the unity of love, power, and justice' and the connection between these three aspects is also important in Valerian. It is most clearly expressed in one of the key scenes of the film. This takes place towards the end of the film, when the eponymous hero Valerian (Dane DeHaan) and his partner (both professionally and romantic) Laureline (Cara Delevingne) have discovered the surviving Pearls deep in the heart of Alpha. They have kidnapped Commander Filitt in order to force him to reveal the truth. As the Pearl emperor Haban-Limaï remarks, they are still under threat from him: 'We are survivors, but that makes us witnesses of a past humans want to forget'. After relaying their story to Valerian and Laureline, the emperor puts his case to Valerian: 'You know our story now, our destiny is in your hands.' It is up to Valerian to decide what is just. The key to saving the Pearls is handing over a valuable creature-the last of its kind-that is currently official government property and in the care of Laureline. Valerian wants to hold on to it and leave the issue for the courts to decide, but Laureline feels it is their duty to enact justice. Interestingly, their argument quickly links the notion of justice to love:

Valerian: I'm a soldier, I play by the rules. It's what makes me who I am.

Laureline: (pauses, tearfully) You see, that's why I don't want to marry you, because you really don't know what love is.

Valerian: Oh, come on, this has nothing to do with love.

Laureline: That's where you're wrong. Love is more powerful than anything else, Valerian. It breaks all the rules and laws and overpowers any army or government. Just look at her [the Pearl Empress]. For one second put yourself in her position. She lost all her people and her child and is willing to forgive. That's real love. It's the trust you place in someone else and I thought I could be that someone else for you. But clearly ...

Valerian: (interrupts) You can, you are, I'd die for you.

Laureline: I'm not asking you to die for me, I'm asking you to trust me.

The film here plays with the romantic notion of the hero sacrificing his life for the heroine. Yet, what Laureline requires is not a dramatic gesture of heroic death, but trust and an acknowledgement of the suffering of the Pearls, a suffering they can mitigate. When Valerian is finally willing to accept this, he allows Laureline to carry out her act of neighbourly love by giving up the valuable creature in her possession. On the surface, there seems to be a tension here between love and justice, but on closer inspection, it is more the case that two different concepts of justice are at stake here. Valerian acknowledges the injustice done to the Pearls, but wants the law to take care of it. He wants to follow the rules and due process. Laureline's notion of justice is more strongly guided by compassion. She strongly believes that as they are able to act here and now to help the Pearls, they should not simply pass on the decision to the authorities. She takes personal responsibility for the situation, even though she was not involved in and, until recently, ignorant of their destiny. When handing over the creature, she remarks that 'we [as humans] are to blame for the loss of your planet and we' $\mathrm{d}$ be honoured to help you get it back.' Wadell (2014, p. 387) argues that the 'crucial point [of agapic love] is that our hearts are sorrowful at the sight of others' sufferings precisely because the love of charity enables us to see them not as strangers to us but as neigbors who, like us, have been welcomed by God into the fellowship of charity.' If one reads the Pearls with their superior knowledge, power and 
ethics as quasi-divine in the sense of Schwartz Ellis's sky gods, then their capacity for sacrificial love can be read in agapic terms. Such a love, appropriating C. S. Lewis' notion of divine love, 'admitted to the human heart, transforms not only Gift-love, but our Need-love; not only our Need-love of Him, but also our Need-love of one another' (Lewis 1960, p. 133). Once Valerian allows himself to be moved by the Pearl's plight, he is also able to better understand and express the love that Laureline wants him to show towards her. This divine, sacrificial love for the neighbour does not supersede or substitute romantic love, but rather romantic love is 'summoned to become [a mode] of Charity while also remaining' natural, preferential love (Lewis 1960, p. 133).

Valerian's transformation is in contrast to commander Filitt, who continues to defend his actions by arguing that he put the (economic) wellbeing of his own species first. His love, if we can call it that at all, is primarily selfish and limited to the flourishing of his own interest group, ignoring the command given in Leviticus (19:34): 'you shall love the alien as yourself'. Filitt's attempt to eradicate the Pearls a second time and his unwillingness to reflect on the events of the past, is in contrast to the attitude taken by the Pearls. When the emperor tells their story, he acknowledges that 'time has not dimmed the memories of our loss, but it has allowed us to let go of our anger towards those responsible'. Here, he expresses a notion of forgiveness, as forswearing of resentment as opposed to forgetting, which enables the Pearls to rebuild their lives and ultimately recreate their former existence, albeit in a virtual way. In contrast, Filitt's refusal to ask for or even accept this forgiveness is ultimately his downfall. As the emperor tells him: 'You are your own worst enemy, commander. Unless you make peace with the past, you have no future.' Filitt fails to grasp the chance for redemption that is presented to him. As Lewis has pointed out, we do not lack opportunities for practicing love for the neighbour and thus turn our need-loves into gift-loves, yet it is up to us to recognise them. They are 'provided by those frictions and frustrations that [are] unmistakable evidence that (natural) love is not going to be "enough"-unmistakable, unless we are blinded by egotism' (Lewis 1960, p. 135). Unlike Valerian, Filitt remains blind to a love that transcends his short-sighted egoism.

On a more general level, Valerian is also a good example of what I mentioned earlier with regard to the portrayal of love in cinema. On the surface, the film is a romantic love story between Valerian and Laureline. Yet, by focussing on this familiar trope, viewers might easily overlook other aspects of love, such as the ones highlighted above. The cited dialogue indicates an attempt by Besson to challenge these common assumptions and point the viewer towards a wider sense of love, which is at play here. Taliaferro (2012, p. 183) argues that 'redeeming love can be dynamic, for it is the kind of love that longs for the beloved to come to a life of true fulfillment'. Reading this from a Christian perspective, for him, the ultimate goal of this fulfilment lies in 'a redeemed identity in Christ' (Taliaferro 2012, p. 183). But, this can also be interpreted in a more broadly religious sense of opening ourselves up to sacrificial love, not just for those closest to us, but to all creation, human or alien. 'It is that extraordinary vision of a generous, overflowing, immutable, divine love which seeks our love in return that has led so many [... ] to affirm the line [ ... ] God is love' (Taliaferro 2012, p. 184).

\section{Conclusion-Neighbour love in Luc Besson's science fiction}

Drawing once again on Eliade (1958), Schwartz Ellis (2004, p. 145) suggests that the benevolent alien, 'seeming to burst out of nowhere into the everyday world, may be regarded as a hierophany, a manifestation of the sacred.' Unlike in the 1970s films discussed by Schwartz Ellis, alien creatures have become a common occurrence in the more recent science fiction worlds created by Besson. However, the key aliens in both films still stand out as extraordinary beings and can therefore be considered as manifestations of the divine. In The Fifth Element, Leeloo quite literally bursts from the sky into Korben's world. And her quality as a saviour figure has been equally outlined. The aspect of hierophany is also present in Valerian, as the Pearls as a species are considered non-existent, so their discovery at the heart of Alpha still comes as a revelation. In both cases, the contact with the 'sacred' prompts the main characters-and by extension the audience-to re-evaluate the meaning of love. Both Korben and Valerian are soldiers known for their courage, as well as their somewhat unorthodox approaches. 
Yet the encounter with the divine other requires both to show their vulnerability and have faith rather than simply a plan.

Although both films feature a wide range of alien creatures-good, bad or ambivalent-the worst threat in both cases are the humans. True, in The Fifth Element evil appears from outer space. But, it seems to operate in partnership with the greedy magnate Zorg (Gary Oldman), who is key to its (initial) success. In Valerian, there is little indication that any of the thousands of alien races living on Alpha is particularly aggressive towards humans. Even the Boulan Bathors, who are attempting to present Laureline as a delicacy to their king, are shown as charmingly naive and quirky creatures that are not really a threat as long as you stay away from them. It is never made clear if the war, in which Mül was destroyed as collateral damage, took place between humans and aliens or between human factions, but the viewer only ever sees the vicious and coldly calculating acts of the human commander.

With regard to the benevolent aliens analysed by Schwartz Ellis (2004, p. 147), she suggests that like 'all sacred beings, each alien has extra-ordinary power.' While this is clearly not the case for all alien species that feature in Besson's films, it is true of Leeloo and the Pearls. And it might be that because of their status as 'divine beings', they are also able to impart agapic love upon the humans, either as a channel for the divine light that saves Earth or more subtly in form of lessons in forgiveness and reconciliation. They show us the meaning of love, a love that takes risks, makes sacrifices and reaches out to our fellow creatures. Both The Fifth Element and Valerian and the City of a Thousand Planets offer a forceful example of this kind of love and consequently encourage us to love our neighbour-alien or not-as ourselves.

Funding: This research received no external funding.

Conflicts of Interest: The authors declare no conflict of interest.

\section{Filmography}

Aliens (1986), directed by James Cameron. Twentieth Century Fox.

Alien vs. Predator (aka AVP) (2004), directed by Paul W. S. Anderson. Twentieth Century Fox.

Avatar (2009), directed by James Cameron. Twentieth Century Fox.

Cocoon (1985), directed by Ron Howard. Twentieth Century Fox.

Contact (1997), directed by Robert Zemeckis, Warner Bros.

Day the Earth Stood Still, The (1951), directed by Robert Wise. Twentieth Century Fox.

E.T. the Extra-Terrestrial (1982), directed by Steven Spielberg. Universal Pictures.

Ex Machina (2014), directed by Alex Garland. Universal Pictures.

Fifth Element, The (aka Le cinquième élément) (1997), directed by Luc Besson. Gaumont.

Independence Day (1996), directed by Roland Emmerich. Twentieth Century Fox.

Invaders from Mars (1953), directed by William Cameron Menzies. Edward L. Alperson Productions

Invasion of the Body Snatchers (1956), directed by Don Siegel. Walter Wanger Productions.

Invasion of the Body Snatchers (1978), directed by Philip Kaufman. Solofilm.

Killers from Space (1954), directed by W. Lee Wilder. Planet Filmplays.

Man of Steel (2013), directed by Zack Snyder. Warner Bros.

Mars Attacks! (1996), directed by Tim Burton. Tim Burton Productions.

Matrix, The (1999), directed by The Wachowski Brothers. Warner Bros.

Men in Black (1997), directed by Barry Sonnenfeld. Columbia Pictures.

Star Wars: Episode IV_-A New Hope (aka Star Wars) (1977), directed by George Lucas. Lucasfilm.

Star Trek: The Motion Picture (1979), directed by Robert Wise. Paramount Pictures.

Thing from Another World, The (1951), directed by Christian Nyby. RKO Radio Pictures.

Transcendence (2014), directed by Wally Pfister. Warner Bros.

Valerian and the City of a Thousand Planets (2017), directed by Luc Besson. EuropaCorp.

War of the Worlds, The (1953), directed by Byron Haskin. Paramount Pictures.

War of the Worlds (2005), directed by Steven Spielberg. Paramount Pictures. 


\section{References}

Brown, William. 2007. Sabotage or espionage? Transvergence in the works of Luc Besson. Studies in French Cinema 7: 93-106. [CrossRef]

Byrge, Duane. 1997. 'The Fifth Element: THR's 1997 Review, The Hollywood Reporter. Available online: https: / www.hollywoodreporter.com/review / fifth-element-review-1997-movie-1109146 (accessed on 1 May 2018).

Cubitt, Sean. 2002. Delicatessen: Eco-Apocalypse in the New French Science Fiction Cinema. In Aliens R Us: The Other in Science Fiction Cinema. Edited by Ziauddin Sardar and Sean Cubitt. London: Pluto Press, pp. 18-33.

Eliade, Mircea. 1958. Patterns in Comparative Religion. Translated by Rosemary Sheed. New York: New American Library.

Eliade, Mircea. 1962. The Two and the One. Translated by J. M. Cohen. Chicago: Chicago University Press.

Flesher, Paul V. M., and Robert Torry. 2007. Film and Religion. In An Introduction. Nashville: Abington Press.

Hansen, Miriam Batu. 1997. Introduction. In Theory of Film. Edited by Siegfried Kracauer. Princeton: Princeton University Press, pp. xxxiii-xxxiv.

Hayward, Susan. 1998. Luc Besson. Manchester: Manchester University Press.

Hayward, Susan. 1999. Besson's "Mission Elastoplast": Le Cinquième élément (1997). In French Cinema in the 1990s: Continuity and Difference. Edited by Phil Powrie. Oxford: Oxford University Press, pp. 246-57.

Lewis, Susan, and Phil Powrie. 2009. The Films of Luc Besson: Master of Spectacle. Manchester: Manchester University Press.

Lewis, Clive Staples. 1952. Mere Christianity. London: HarperCollins.

Lewis, Clive Staples. 1960. The Four Loves. New York: Harcourt.

Lindberg, Carter. 2008. Love: A brief history through Western Christianity. Oxford: Blackwell.

Luther, Martin. 1520. On the Freedom of a Christian. In Luther's Works. Edited by Jaroslav Pelikan and Helmut T. Lehmann. 55 vol. Fortress (This Edition 1955-86). St. Louis: Concordia/Philadelphia.

Lyden, John C. 2003. Film as Religion. Myths, Morals, and Rituals. New York and London: New York University Press.

Magerstädt, Sylvie. 2014. Body, Soul and Cyberspace in Contemporary Science Fiction Cinema: Virtual Worlds and Ethical Problems. Basingstoke: Palgrave Macmillan.

McCarthy, Todd. 2017. Valerian and the City of a Thousand Planets: Film Review. The Hollywood Reporter. Available online: https: / / www.hollywoodreporter.com/review/valerian-city-a-thousand-planets-review1019847 (accessed on 1 May 2018).

Miles, Margaret R. 1996. Seeing and Believing. Religion and Values in the Movies. Boston: Beacon Press.

Nygren, Anders. 1953. Agape and Eros. Translated by Philip S. Watson. Philadelphia: The Westminster Press.

Rabin, Nathan. 2018. Follywood: How Valerian Earns Its Place among Film's Strangest Big-Budget Flops. The Guardian. Available online: https:/ /www.theguardian.com/film/2017/aug/04/valerian-jupiter-ascendingscience-fiction-film-flops (accessed on 30 June 2018).

Reid, Joe. 2018. Weekend Watch: 'Valerian and the City of a Thousand Planets Is a Shockingly Non-Crappy Sci-Fi Romp', Decider. Available online: https:/ / decider.com/2018/01/05/weekend-watch-valerian-and-the-cityof-a-thousand-planets / (accessed on 30 June 2018).

Sardar, Ziauddin. 2002. Introduction. In Aliens R Us: The Other in Science Fiction Cinema. Edited by Ziauddin Sardar and Sean Cubitt. London: Pluto Press, pp. 1-17.

Schwartz Ellis, Carol. 2004. With Eyes Uplifted: Space Aliens as Sky Gods. In Liquid Metal: The Science Fiction Film Reader. Edited by Sean Redmond. London and New York: Wallflower Press, pp. 145-53.

Taliaferro, Charles. 2012. Love. In Being Good. Christian Virtues for Everyday Life. Edited by Michael W. Austin and R. Douglas Geivett. Grand Rapids: Eerdmans.

Tillich, Paul. 1960. Love, Power, and Justice. New York: Oxford University Press.

Wadell, Paul J. 2014. Charity: How Friendship with God Unfolds in Love for Others. In Virtues and Their Vices. Edited by Kevin Timpe and Craig A. Boyd. Oxford: Oxford University Press, pp. 369-90.

(C) 2018 by the author. Licensee MDPI, Basel, Switzerland. This article is an open access article distributed under the terms and conditions of the Creative Commons Attribution (CC BY) license (http:/ / creativecommons.org/licenses/by/4.0/). 